\title{
DESKRIPSI HASIL BELAJAR BANGUN RUANG SISI DATAR PADA PENERAPAN DIRECT INSTRUCTION DENGAN ALAT PERAGA DIKELAS VIII F MTS N 02 KOTA BENGKULU TAHUN AJARAN 2016/2017
}

\author{
Ari Supriadi ${ }^{1}$, Rusdi $^{2}$, Della Maulidiya ${ }^{3}$ \\ ${ }^{1,2,3}$ Program Studi Pendidikan Matematika JPMIPA FKIP Universitas Bengkulu \\ email : ${ }^{1}$ arisupriadi84@gmail.com, ${ }^{2}$ rusdipendmat12@gmail.com, ${ }^{3}$ della.maulidiya@gmail.com
}

\begin{abstract}
Abstrak
Tujuan Penelitian ini adalah memperoleh deskripsi hasil belajar materi bangun ruang sisi datar pada penerapan direct instruction dengan alat peraga di kelas VIII F MTs N 02 Kota Bengkulu. Metode penelitian yang digunakan yaitu deskripsi kuantitatif. Subjek penelitian ini adalah 27 siswa kelas VIII F MTs N 02 Kota Bengkulu semester genap tahun ajaran 2016/2017. Instrumen yang digunakan adalah lembar hasil belajar siswa yang terdiri dari 4 soal essay. Langkah - langkah pembelajaran direct instructon dengan alat peraga yaitu orientasi, presentasi dengan alat peraga bangun ruang sisi datar, praktik terstruktur dengan alat peraga bangun ruang sisi datar, praktik dibawah bimbingan guru, dan praktik mandiri. Rata-rata skor tiap indikator soal yang dikerjakan siswa yaitu : indikator $1=17,40$ (baik), indikator $2=25,85$ (baik), indikator $3=11,37$ (cukup baik), indikator $4=11,12$ (cukup baik), indikator $5=21,44$ (baik), indikator $6=15,44$ (baik), indikator $7=20,25$ (baik), indikator $8=18,29$ (baik), indikator $9=35,7$ (baik), dan indikator $10=45,4$ (baik).
\end{abstract}

Kata kunci : deskripsi, hasil belajar, direct instruction.

\begin{abstract}
The purpose of this study is to obtain a description of the results of learning materials wake up a flat side room on the application of direct instruction with props in class VIII F MTs N 02 Kota Bengkulu. The research method used is quantitative description. The subject of this research is 27 students of class VIII F MTs N 02 Kota Bengkulu even semester of academic year 2016/2017. The instrument used is a sheet of student learning outcomes consisting of 4 essay questions. Direct instruction steps with orientation aids, presentation with props wake up a flat side room, structured practice with props wake up a flat space, practice under teacher guidance, and independent practice. The average score of each indicator about the student's work is: indicator $1=17,40$ (good), indicator $2=25,85$ (good), indicator $3=11,37($ good enough $)$, indicator $4=11,12($ Good enough $)$, indicator $5=21.44(\mathrm{good})$, indicator $6=15.44(\mathrm{good})$, indicator $7=20.25(\mathrm{good})$, indicator $8=18.29(\mathrm{good})$, indicator $9=35.7$ $($ Good $)$, and indicator $10=45,4(\mathrm{good})$.
\end{abstract}

Keywords : descriptions of learning outcomes; direct instruction.

\section{PENDAHULUAN}

Perubahan kurikulum 2013 menghendaki peran aktif siswa dalam belajar, namun tidak mengurangi peran aktif guru dalam belajar. Sehingga, guru perlu melakukan variasi dalam proses pembelajaran, misalnya dengan bantuan alat peraga dalam menyampaikan materi pelajaran dan membimbing latihan saat siswa mengerjakan soal. Direct instruction merupakan suatu model pendekatan mengajar yang dapat membantu siswa didalam mempelajari dan menguasai keterampilan dasar serta memperoleh informasi selangkah demi selangkah (Fathurrohman, 2015: 167). Keterampilan dasar yang dimaksud dapat berupa aspek kognitif maupun psikomotorik, dan juga informasi lainna yang merupakan landasan untuk membangun hasil belajar yang lebh kompleks. Direct instrucction dirancang untuk penguasaan pengetahuan prosedural, pengetahuan deklaratif (pengetahuan faktual) serta berbagai keterampilan (Suprijono, 2009: $50)$.

Langkah-langkah direct instruction menurut Joyce, Weil, dan Calhoun (2009 : 427) terdiri dari lima tahap aktivitas ; yakni 
orientasi, presentasi, praktik yang terstruktur, praktik dibawah bimbingan, dan praktik mandiri. Namun, dimodifikasi dengan alat peraga sehingga langkah-langkah direct instruction dengan alat peraga sebagai berikut :

1. Orientasi

2. Presentasi dengan bantuan alat peraga

3. Praktik yang terstruktur dengan bantuan alat peraga

4. Praktik dibawah bimbingan guru

5. Praktik mandiri.

Adapun alat peraga yang digunakan dalam direct instruction dengan alat peraga sebagai berikut :
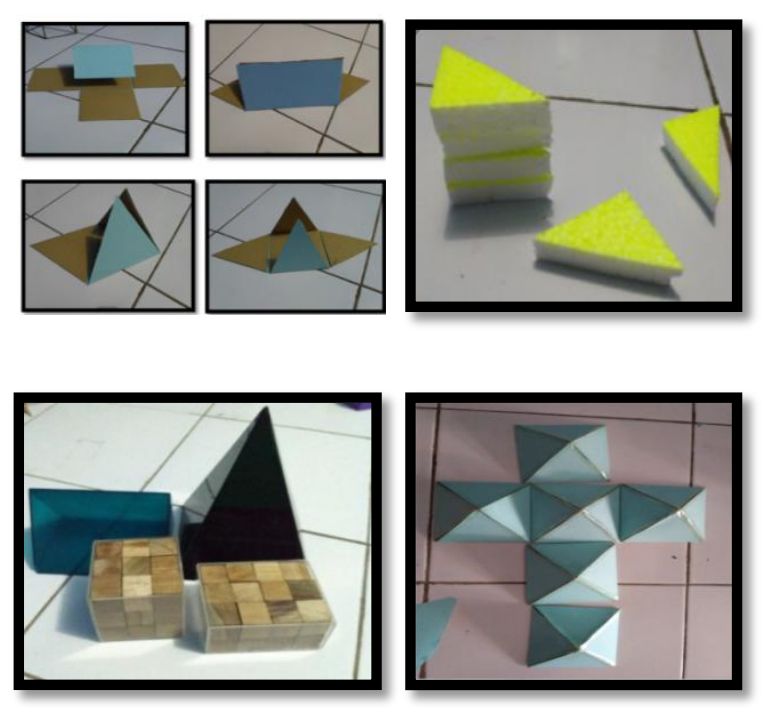

\section{Gambar 1. Alat peraga bangun ruang sisi datar yang digunakan.}

Artikel ini ditulis untuk mendeskripsikan hasil belajar. Hasil belajar diperoleh melalui tes hasil belajar siswa pada materi bangun ruang sisi datar setelah pembeajaran dengan direct instruction dengan alat peraga. Sudjana (2011: 35) menyatakan tes sebagai alat penilaian adalah pertanyaan - pertanyaan yang diberikan kepada siswa dalam bentuk lisan (tes lisan), dalam bentuk tulisan (tes tulisan), atau dalam bentuk perbuatan (tes tindakan). Tes yang dilakukan adalah tes uraian.

\section{METODE}

Untuk menjawab permasalahan pada artikel ini digunakan deskripsi kuantitatif berdasarkan hasil tes siswa. Tes dilakukan 3 kali dengan kompetensi dasar (KD) dan indikator tes sebagai berikut :

1. Indikator tes I

KD : 3.9 Menentukan luas permukaan dan volume bangun ruang sisi datar

Indikator :

1. Menentukan luas permukaan kubus.

2. Menemukan jaring-jaring dan menetukan luas permukaan balok.

3. Menentukan luas permukaan prisma.

4. Menentukan luas permukaan limas.

2. Indikator tes II

KD : 3.9 Menentukan luas permukaan dan volume bangun ruang sisi datar.

Indikator :

1. Menentukan volume kubus.

2. Menentukan volume balok.

3. Menentukan volume prisma.

4. Menentukan volume limas.

3. Indikator tes III

KD : 3.10 Menaksir luas permukaan dan menentukan volume bangun ruang sisi datar tak beraturan.

Indikator :

1. Menaksir luas permukaan bangun tak beraturan.

2. Menentukan volume bangun ruang sisi datar tak beraturan.

Skor minimum pada soal tiap indikator adalah 0, dan skor maksimum tiap inikator bervariasi tergantung dengan kesulitan soal. skor maksimum pada soal tiap indikator dapat dilihat pada tabel berikut :

Tabel 1. Penilaian tiap indikator.

\begin{tabular}{|c|c|c|}
\hline Indikator & $\begin{array}{c}\text { Skor } \\
\text { Maksimum }\end{array}$ & Banyak soal \\
\hline 1 & 25 & 1 \\
\hline 2 & 30 & 1 \\
\hline 3 & 25 & 1 \\
\hline 4 & 20 & 1 \\
\hline 5 & 28 & 1 \\
\hline 6 & 21 & 1 \\
\hline 7 & 28 & 1 \\
\hline 8 & 23 & 1 \\
\hline 9 & 48 & 2 \\
\hline 10 & 52 & 2 \\
\hline
\end{tabular}


Kriteria capaian untuk setiap indikator menggunakan skala linkert dengan menggunakan rumus sebagai berikut :

Kisaran nilai untuk tiap kriteria $=$ (Skor maksimum -skor minum ) jumlah kriteria

Contoh capaian untuk indikator 1 :

Kisaran nilai tiap kriteria $=\frac{(25-0)}{3}=8,3$

Kriteria yang dinilai pada capaian hasil belajar adalah kurang, cukup baik, dan baik. Kriteria capaian setiap indikator dapat dilihat pada tabel dibawah ini :

Tabel 2. Kriteria capaian tiap indikator

\begin{tabular}{|c|c|c|c|}
\hline \multirow{2}{*}{$\begin{array}{c}\text { Indi- } \\
\text { kator }\end{array}$} & \multicolumn{3}{|c|}{ Kriteria } \\
\cline { 2 - 4 } & Kurang & Cukup & Baik \\
\hline $\mathbf{1}$ & $0-8,3$ & $8,4-16,7$ & $16,8-25$ \\
\hline $\mathbf{2}$ & $0-10$ & $11-20$ & $21-30$ \\
\hline $\mathbf{3}$ & $0-8,3$ & $8,4-16,7$ & $16,8-25$ \\
\hline $\mathbf{4}$ & $0-6,7$ & $6,8-13,5$ & $13,6-20$ \\
\hline $\mathbf{5}$ & $0-9,3$ & $9,4-18,7$ & $18,8-28$ \\
\hline $\mathbf{6}$ & $0-7$ & $8-14$ & $15-21$ \\
\hline $\mathbf{7}$ & $0-9,3$ & $9,4-18,7$ & $18,8-28$ \\
\hline $\mathbf{8}$ & $0-7,6$ & $7,7-15,3$ & $15,4-23$ \\
\hline $\mathbf{9}$ & $0-16$ & $17-33$ & $34-48$ \\
\hline $\mathbf{1 0}$ & $0-17,3$ & $17,4-34,7$ & $34,8-52$ \\
\hline
\end{tabular}

Selain itu hasil belajar juga diolah dengan statistik inferensial dengan mencari nilai ratarata sebagai berikut :

Keterangan:

$$
\bar{X}=\frac{\sum X}{N}
$$

$\bar{X} \quad=$ Rata-rata

$\sum X=$ jumlah seluruh skor

$\mathrm{N}=$ Banyaknya subjek

Ketuntasan klasikal belajar siswa juga dapat dihitung dengan rumus berikut

$$
\mathrm{p}=\frac{\sum \text { siswa yang tuntas belajar }}{\sum \text { siswa }} \times 100 \%
$$

Ket: P : ketuntasan belajar klasikal

\section{HASIL DAN PEMBAHASAN}

Hasil belajar yang diperoleh tiap tes diolah dengan mencari nilai rata-rata dan ketuntasan klasikal untuk melihat capaian hasil belajar secara umum.

Tabel 3. Rata-rata nilai dan ketuntasan klasikal

\begin{tabular}{|c|c|c|c|}
\hline Tes & KD & $\begin{array}{c}\text { Rata- } \\
\text { Rata Nilai }\end{array}$ & $\begin{array}{c}\text { \% } \\
\text { Ketuntasan }\end{array}$ \\
\hline I & 3.9 & 66,48 & $37,03 \%$ \\
\hline II & 3.9 & 75,34 & $62,96 \%$ \\
\hline III & 3.10 & 81,14 & $77,78 \%$ \\
\hline
\end{tabular}

Dari tabel diatas dapat disimpulkan pada kompetensi dasar 3.9, menentukan luas permukaan da volume bangun ruang sisi datar pada tes I siswa memiliki rata-rata dan ketuntasan klasikal yang masih rendah dam pada kompetensi dasar 3.10, menaksirkan luas permukaan dan volume bangun ruang sisi datar tan beraturan mencapai rata-rata nilai siswa dan klasikal yang bagus. Berikut akan diuraikan capaian hasil belajar setiap indikator tes serta proses belajar tahap direct instruction dengan alat peraga.

\section{A. Analisis capaian hasil belajar tiap indikator tes}

Rata-rata skor tiap indikator dilihat dari tabel 4 berikut

Tabel 4. Analisis Capaian hasil belajar tiap indikator.

\begin{tabular}{|c|c|c|c|c|c|}
\hline Tes & $\begin{array}{c}\text { Indi- } \\
\text { kator }\end{array}$ & $\begin{array}{c}\text { Skor } \\
\text { Maks }\end{array}$ & $\begin{array}{c}\text { Rata- } \\
\text { rata } \\
\text { Skor }\end{array}$ & Kriteria & $\begin{array}{c}\text { Rata- } \\
\text { rata tes }\end{array}$ \\
\hline \multirow{7}{*}{ I } & 1 & 25 & 17,40 & Baik & \multirow{1}{*}{16,43} \\
\cline { 2 - 5 } & 2 & 30 & 25,85 & Baik & \\
\cline { 2 - 5 } & 3 & 25 & 11,37 & $\begin{array}{c}\text { Cukup } \\
\text { Baik }\end{array}$ & \multirow{1}{*}{16} \\
\cline { 2 - 5 } & 4 & 20 & 11,12 & $\begin{array}{c}\text { Cukup } \\
\text { Baik }\end{array}$ & \\
\hline \multirow{4}{*}{ II } & 5 & 28 & 21,44 & Baik & \multirow{1}{*}{18,85} \\
\cline { 2 - 5 } & 6 & 21 & 15,44 & Baik & \\
\cline { 2 - 5 } & 7 & 28 & 20,25 & Baik & \\
\cline { 2 - 5 } & 8 & 23 & 18,29 & Baik & \\
\hline III & 9 & 48 & 35,7 & Baik & \multirow{2}{*}{20,27} \\
\cline { 2 - 5 } & 10 & 52 & 45,4 & Baik & \\
\hline
\end{tabular}

Dari tabel diatas, dapat dilihat pada tes I mencapai rata-rata 16,43 dengan kriteria cukup 
baik, tes II mencapai rata-rata 18,85 dengan kriteria baik, dan tes III mencapai rata-rata 20,27 dengan kriteria baik. Adapun analisis hasil belajar siswa tiap indikator dilakukan untuk mendeskripsikan capaian hasil belajar secara detail.

Indikator 1, yaitu menentukan luas permukaan kubus. Pada indikator ini hanya $11,2 \%$ siswa yang mendapat skor maksimal. Dan 3,7\% siswa tidak menjawab. Artinya $85,1 \%$ siswa masih melakukan kesalahan pada soal indikator 1 .

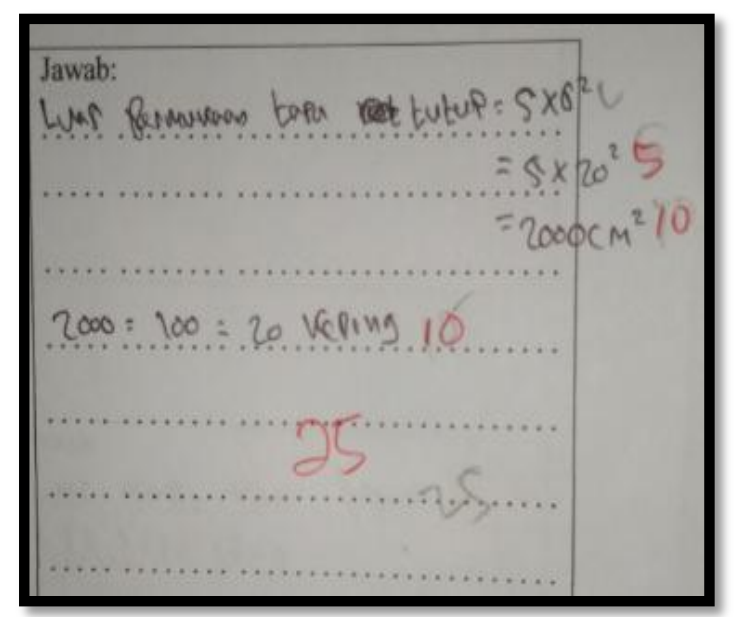

Gambar 2. Hasil Pengerjaan siswa yang benar pada indikator 1

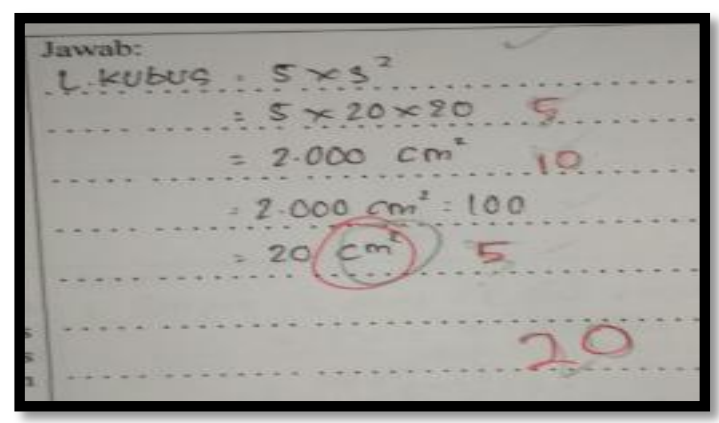

Gambar 3. Contoh kesalahan yang dilakukan siswa pada indikator 1

Indikator 2 yaitu menemukan jaring-jaring dan menentukan luas permukaan balok. pada soal tes indikator 2 ini dibagi menjadi 2, yaitu menenmukan jaring-jaring balok dengan skor 15, dan menentukan luas permukaan balok dengan skor 15. Pada indikator ini, terdapat $59,25 \%$ siswa mendapatkan skor maksimal. Artinya 40,75\% siswa masih melakukan kesalahan pada soal indikator 2 .

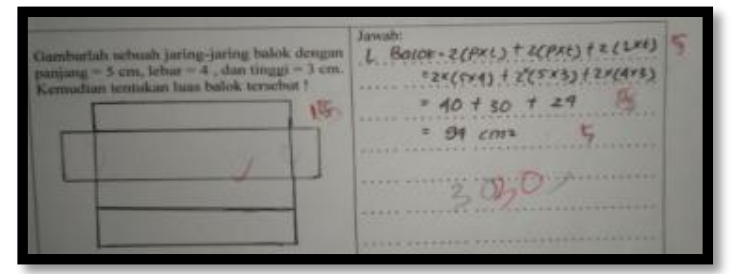

Gambar 4. Contoh jawaban siswa yang mendapatkan skor maksimal pada indikator 1

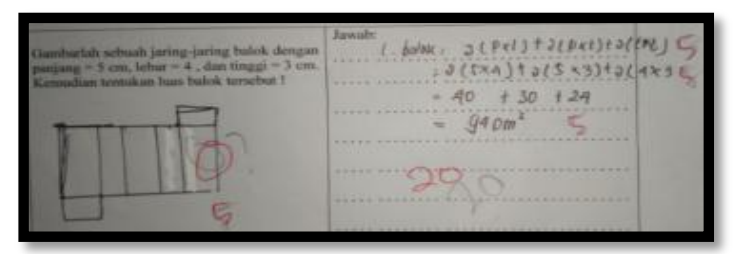

Gambar 5. Contoh kesalahan siswa pada jawaban indikator 2

Indikator 3 yaitu menentukan luas permukaan prisma. Pada indikator ini, tidak ada siswa yang memperoleh skor maksimal yaitu 25. Dan 3,7\% siswa tidak menjawab soal . Artinya, terdapat $96,3 \%$ siswa menjawab soal dengan kesalahan. Kesalahan yang dilakukan siswa dalam mengerjakan soal yaitu : kurang membuat langkah-langkah yang disiapkan rubrik dan menjawab salah pertanyaan.

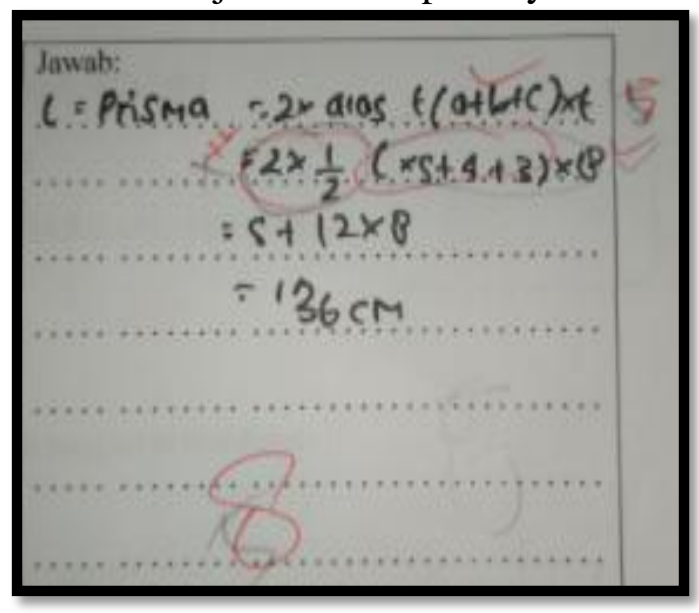

Gambar 6. Contoh pengerjaan siswa yang salah pada indikator 3

Indikator 4 yaitu menentukan luas permukaan limas. Pada indikator ini, tdak ada siswa yang memperoleh nilai maksimal yaitu 20. Dan $3,7 \%$ siswa tidak menjawab pertanyaan. Artinya, 96,3\% siswa masih menjawab pertanyaan dengan kesalahan. Kesalahan yang dilakukan siswa dalam mengerjakan soal yaitu : kurang membuat jawaban sesuai dengan rubrik dan menjawab 
salah pada pertanyaan. kesalahan yang dijawab siswa yaitu $144 \mathrm{~cm}+192 \mathrm{~cm}$, jawaban yang benar adalah $144 \mathrm{~cm}^{2}+192 \mathrm{~cm}^{2}$.

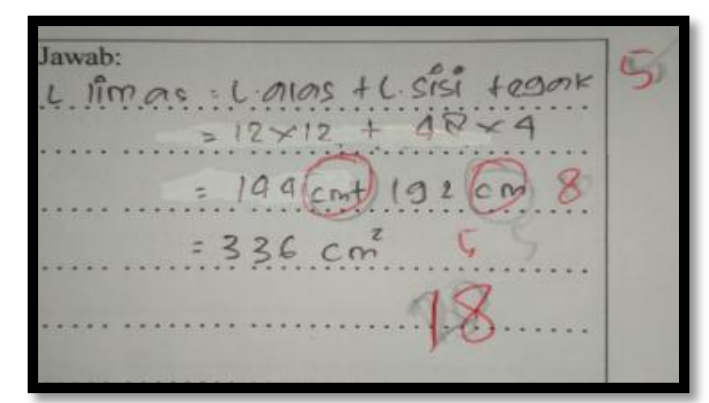

Gambar 7. Contoh kesalahan pengerjaan siswa pada indikator 4

Indikator 5 yaitu menentukan volume kubus. Pada indikator ini, tidak terdapat siswa yang mendapatkan skor maksimal yakni 28 . Artinya, siswa menjawab pertanyaan dengan kesalahan tidak melengkapi jawaban dan menjawab salah dalam perhitungan data.

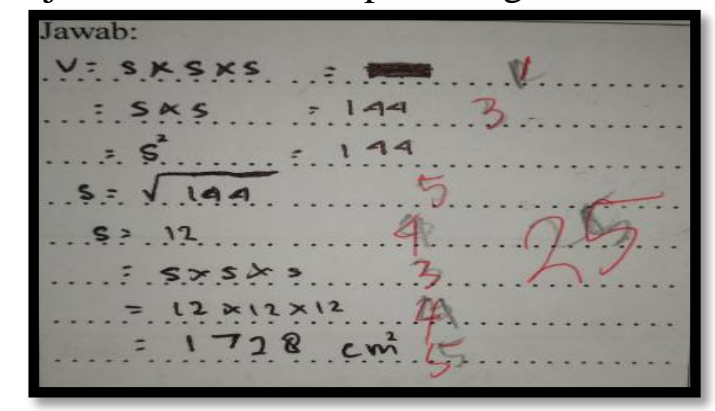

Gambar 8. Contoh pengerjaan siswa pada indikator 5

Indikattor 6 yaitu menentukan volume balok. pada indikator ini, $14,8 \%$ siswa menjawab pertanyaan degan skor maksimal. Artinya, 85,2\% siswa masih menjawab pertanyaan dengan kesalahan dan kurang tepat.

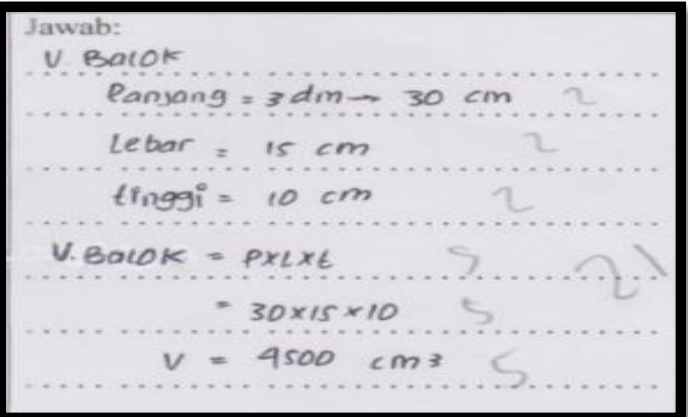

Gambar 9. Jawaban siswa yang benar pada indikator 6

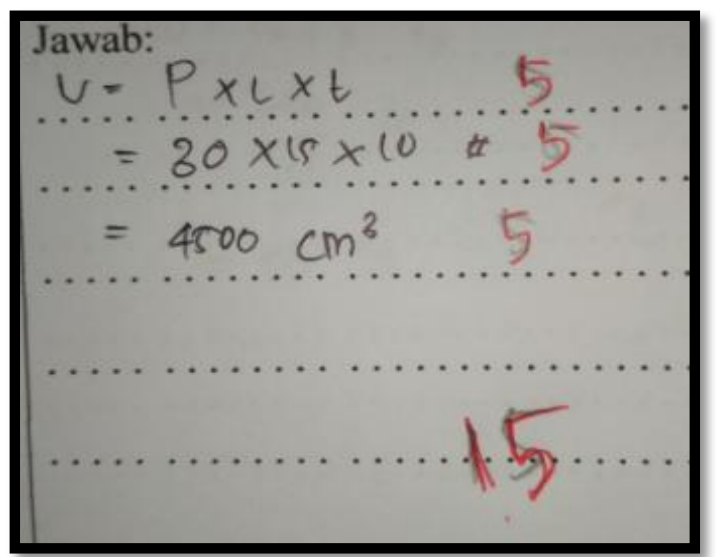

Gambar 10. Contoh kekurangan siswa menjawab soal pada indikator 6

Indikator 7 yaitu menentukan volume prisma. Pada indikator ini tidak ada siswa yang mendapatkan skor maksimal. Artinya, siswa menjawab pertanyaan dengan kekurangan dari rubrik yang disediakan. Kekurangan siswa dalam menulis jawaban yaitu siswa tidak menulis salah satu langkah pada rubrik jawaban yaitu "V=luas trapesium ABCD x tinggi".

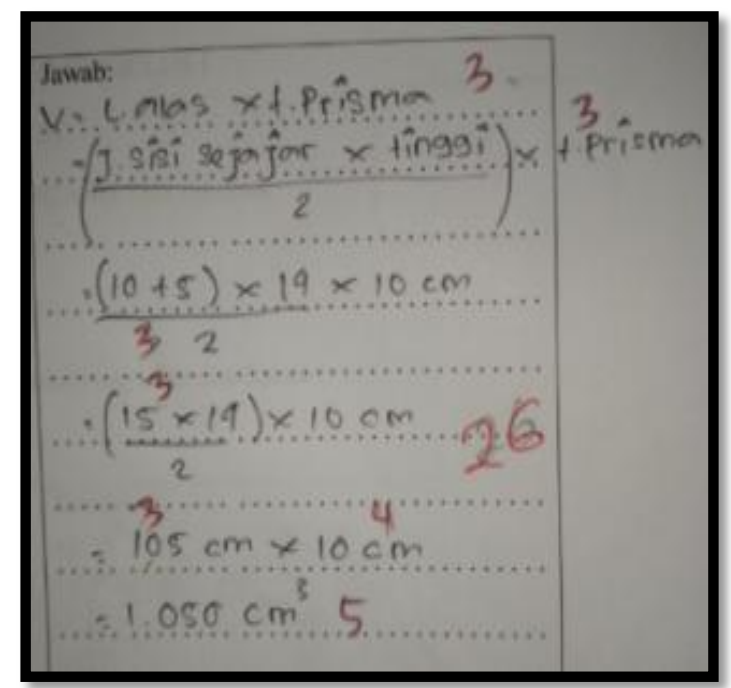

Gambar 11. Contoh kekurangan siswa dalam menjawab soal pada indikator 7

Indikator 8 , pada indikator 8 yaitu menentukan volume limas. pada indikator ini terdapat $7,4 \%$ siswa menjawab soal dengan benar. Artinya, 92,6\% siswa masih melakukan kesalahan dan kekurangan dalam menjawab soal pada indikator ini. 


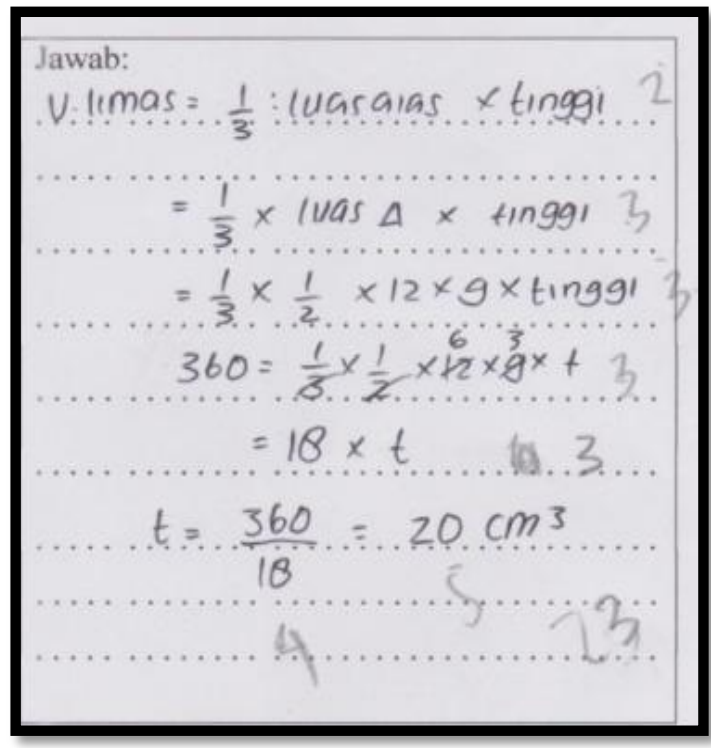

Gambar 12. Jawaban siswa yang benar pada indikator 8

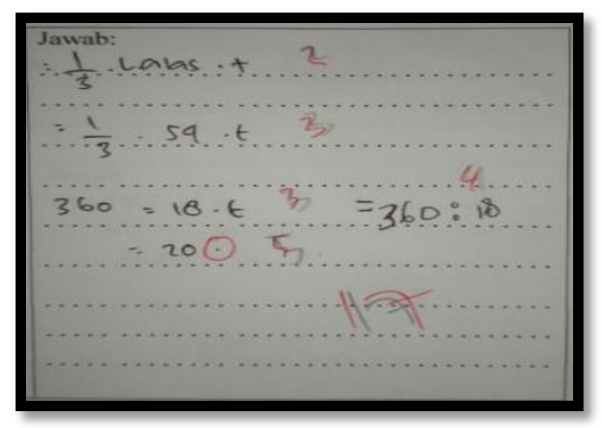

Gambar 13. Contoh kekurangan siswa menjawab soal pada indikator 8

Indikator 9 terdapat 2 soal tentang taksiran luas permukaan bangun tak beraturan dan skor maksimal adalah 48. Pada indikator ini, terdapat $3,7 \%$ siswa mendapatkan skor maksimal. Artinya, terdapat $96,3 \%$ siswa melakukan kesalahan dan kekurangan dalam menjawab soal pada indikator ini.
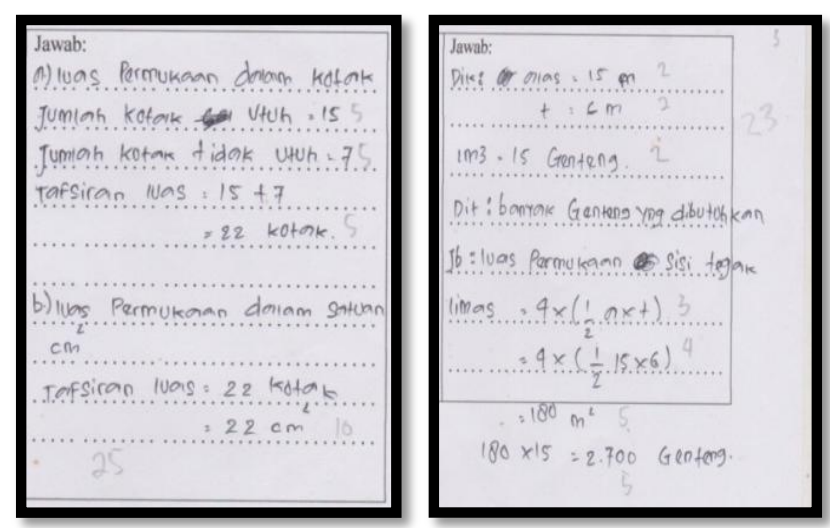

Gambar 14. Jawaban siswa yang benar pada indikator 9
Indikator 10 terdapat 2 soal tentang menentukan volume bangun ruang sisi datar tak beraturan. Pada indikator ini terdapat 14,8\% siswa mendapatkan skor maksimal. Artinya, $85,2 \%$ siswa masih melakukan kesalahan dan kurang tepat dalam menjawab soal pada indikator ini.

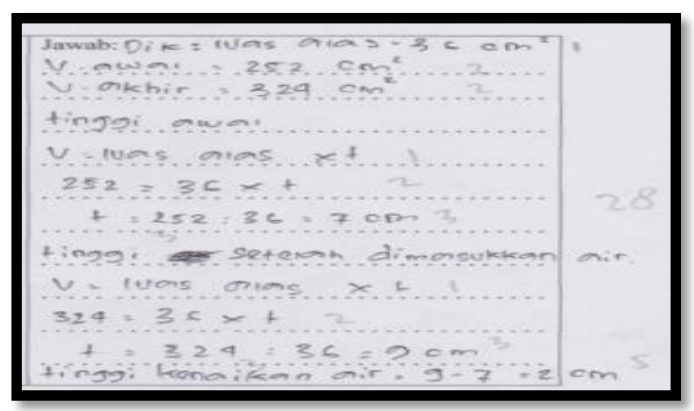

Gambar 15. Contoh jawaban siswa yang benar pada indikator 10.

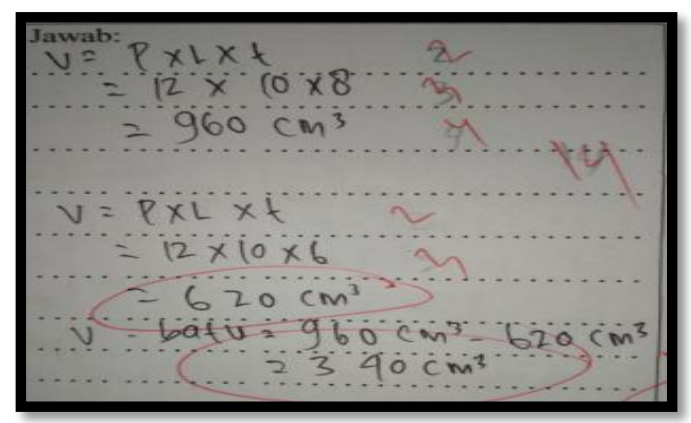

Gambar 16. Contoh kesalahan siswa dalam menjawab soal pada indikator 10

\section{B. Analisis proses direct instruction dengan} alat peraga.

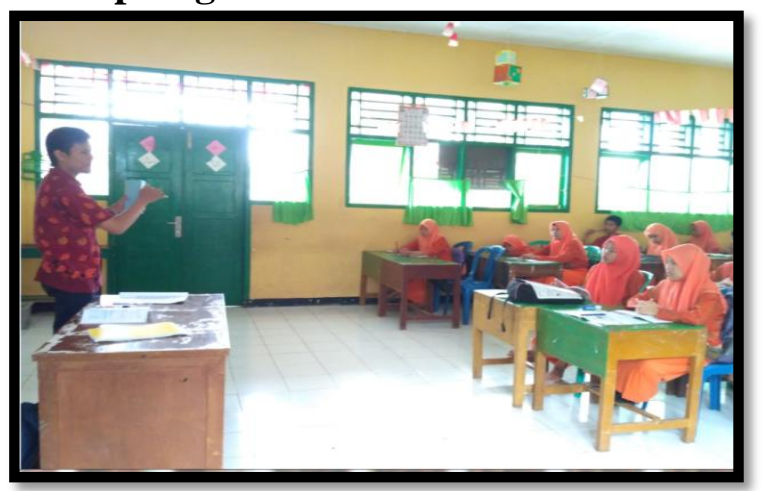

Gambar 17. Guru menyampaikan materi dengan alat peraga

Gambar diatas terlihat guru menjelaskan materi untuk menentukan luas permukaan prisma. Setiap pertemuan guru selalu 
menggunakan alat peraga saat menyampaikan materi. Kegiatan yang dilakukan oleh guru yakni fase 2 : presentasi dengan bantuan alat peraga bangun ruang sisi datar.

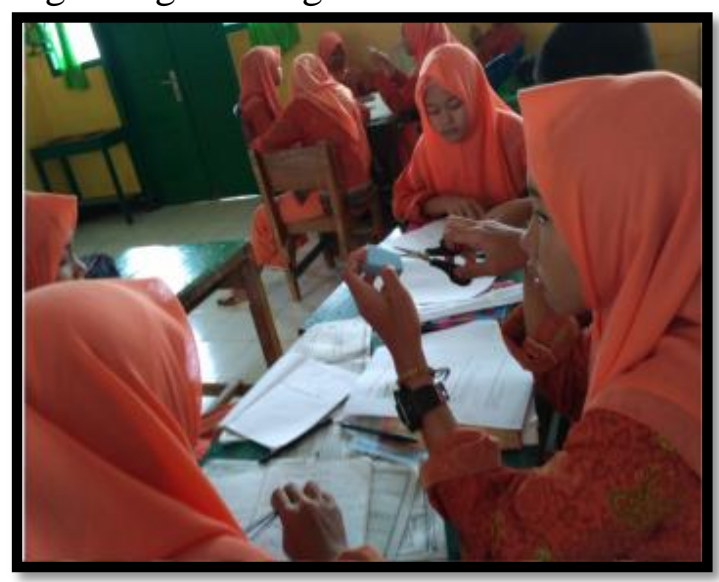

Gambar 17. Siswa memotong alat peraga untuk menemukan jaring-jaring prisma.

Dari gambar diatas, terlihat siswa mengunting alat peraga yang diberikan oleh guru untuk menemukan jaring-jaring prisma pada saat diskusi kelompok. Penggunaan alat peraga pada saat diskusi kelompok selalu menggunakan alat peraga yang telah disediakan guru. Kegiatan ini yaitu pada fase 3: praktik yang terstruktur dengan bantuan alat peraga bangun ruang sisi datar.

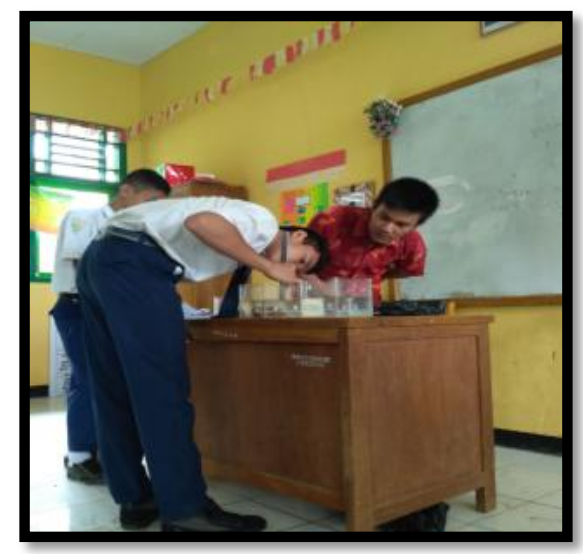

Gambar 18. Siswa mengukur langsung volume bangun ruang sisi datar tak beraturan

Dari gambar diatas, terlihat peran aktif siswa dalam mengukur secara langsung volume bangun ruang sisi datar tak beraturan. Pada gambar 18 juga terlihat peran aktif guru dalam membimbing siswa dalam diskusi. Fase ini yaitu praktik yang terstruktur dengan alat peraga.
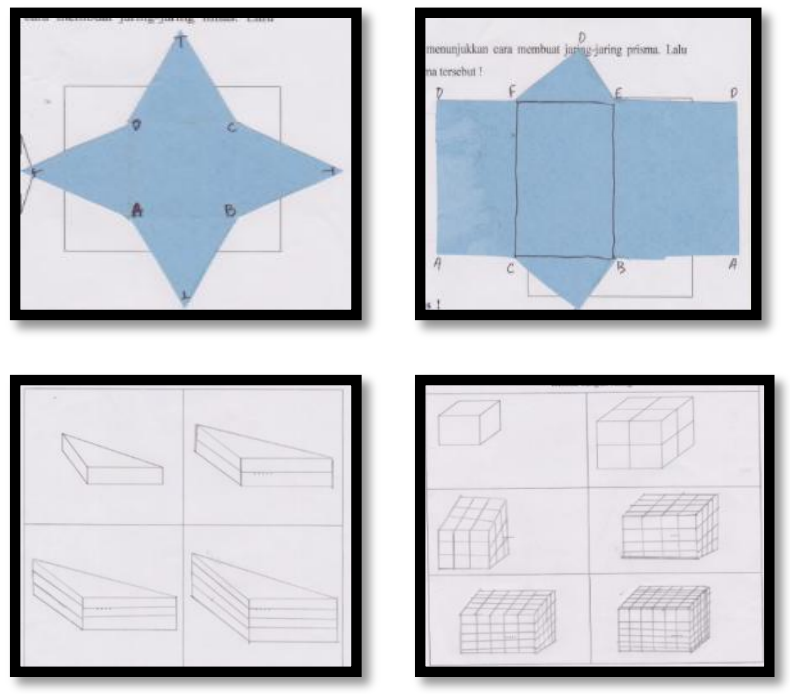

Gambar 19. Hasil jawaban siswa pada LKPD dengan bantuan alat peraga.

\section{PENUTUP}

\section{Simpulan}

Deskripsi hasil belajar sebagai berikut :

1. Capaian siswa untuk kompetensi dasar menentukan luas permukaan dan volume kubus, balok, prisma, dan limas berada pada kriteria baik kecuali untuk indikator menentukan luas permukaan prisma dan indikator menentukan luas permukaan limas yang kriteria cukup baik. Hal tersebut tercapai karena siswa terlibat aktif dalam menggunakan alat peraga secara langsung dalam melakukan pelatihan pada tahap praktik terstruktur. Alat peraga yang diberikan kepada siswa dapat membantu siswa untuk menentukan jaring-jaring, luas permukaan, dan volume bangun ruang sis datar tak beraturan.

2. Capaian siswa untuk kompetensi dasar menaksir luas permukaan dan volume bangun ruang sisi datar tak beraturan berada pada kriteria baik. Hal tersebut tercapai karena siswa terlibat aktif dalam menggunakan alat peraga dalam pelatihan pada tahap praktik terstruktur. Alat peraga yang diberikan kepada siswa dapat membantu siswa untuk menentukan taksiran luas permukaan dan volume bangun ruang sisi datar tak beraturan. 


\section{Saran}

Berdasarkan hasil penelitian tindakan kelas ini, maka saran-saran yang dapat penulis berikan adalah :

1. Pembelajaran direct instruction dengan alat peraga sebaiknya guru membimbing siswa dalam menggunakan alat peraga setiap kelompok dalam mengerjakan LKPD dan membantu siswa dalam memproses data apabila terdapat keliruan.

2. Siswa diberikan kesempatan untuk menggunakan alat pearaga yang berfunsgi untuk menentukan sesuai pemikiran masingmasing kelompok.

3. Lembar kerja hendaknya bisa dikerjakan berkelompok maupun indivindu karena setiap pemikiran siswa berbeda.

\section{DAFTAR PUSTAKA}

Aqib, dkk. 2014. Penelitian tindakan kelas. Bandung. CV. Yrama Widya.

Fathurrohman, Muhammad. 2015. Modelmodel pembelajaran Inovatif. Yogyakarta: Ar-Ruzz Media

Joyce, Weil, dan Calhoun. 2009. Models of Teaching, model-model pengajaran. New Jersey, USA. Pustaka Belajar.

Sudjana. 2011. Penilaian hasil proses belajar mengajar. Bandung. PT Remaja Rosdakarya

Suprijono, Agus.2009. Cooperative Learning teori dan aplikasi PAIKEM. Yogyakarta: Pustaka Belajar. 